\title{
Pharmacokinetic properties of intranasal and injectable formulations of naloxone for community use: a systematic review
}

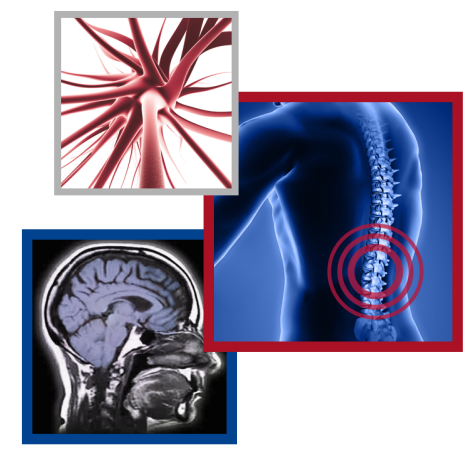

\author{
Shawn A Ryan*,1,2 \& Robert B Dunne ${ }^{3}$ \\ ${ }^{1}$ Department of Emergency Medicine, University of Cincinnati College of Medicine, Cincinnati, OH, 45267 USA \\ ${ }^{2}$ BrightView Health, Cincinnati, OH, 45206 USA \\ ${ }^{3}$ Department of Emergency Medicine, Wayne State University School of Medicine, Detroit, MI, 48202 USA \\ *Author for correspondence: Tel.: +1 513834 7063; Fax: +1 513873 1567; s.ryan@brightviewhealth.com
}

\section{Practice points}

- The US FDA has approved two naloxone products for use by laypersons in community settings for emergency treatment of known or suspected opioid overdose: an intranasal spray with a concentrated naloxone dose of 2 or $4 \mathrm{mg}$ in $0.1 \mathrm{ml}$ and an auto-injector for intramuscular (im.) or subcutaneous (sc.) use with a naloxone dose of 0.4 or $2 \mathrm{mg}$.

- In the absence of head-to-head, comparative efficacy studies, which are not feasible for ethical and logistical reasons, pharmacokinetic data provide important information about effective doses and routes of administration of naloxone for opioid overdose reversal.

- In pharmacokinetic studies, both the approved intranasal spray and the im./sc. auto-injector demonstrated bioequivalence with a previously approved formulation, indicating that naloxone exposure was adequate to reverse an opioid overdose.

- Both the approved intranasal spray and the im./sc. auto-injector demonstrated sufficient plasma exposure within the first 15-20 min after administration.

- Usability studies with laypersons in simulated overdose conditions have found that more than $90 \%$ of participants were able to successfully administer naloxone using the approved intranasal spray or im./sc. auto-injector without prior training; however, these studies have identified critical errors with the proper assembly and use of unapproved intranasal kits, even when training had been provided.

- Approved intranasal naloxone is appropriate for most patients, with the exception of those with known nasal pathology (e.g., polyps and chronic intranasal drug use).

- Providing prescriptions for community-use naloxone may reduce future risk in patients who are receiving chronic opioid therapy for pain control or who have histories of illicit opioid use.

Aim: To assess the pharmacokinetic properties of community-use formulations of naloxone for emergency treatment of opioid overdose. Methods: Systematic literature review based on searches of established databases and congress archives. Results: Seven studies met inclusion criteria: two of US FDA-approved intramuscular (im.)/subcutaneous (sc.) auto-injectors, one of an FDA-approved intranasal spray, two of unapproved intranasal kits (syringe with atomizer attachment) and two of intranasal products in development. Conclusion: The pharmacokinetics of im./sc. auto-injector $2 \mathrm{mg}$ and approved intranasal spray (2 and $4 \mathrm{mg}$ ) demonstrated rapid uptake and naloxone exposure exceeding that of the historic benchmark $(0.4 \mathrm{mg} \mathrm{im}$.), indicating that naloxone exposure was adequate for reversal of opioid overdose.

First draft submitted: 6 November 2017; Accepted for publication: 20 March 2018; Published online: 24 April 2018

Keywords: auto-injector $\bullet$ bioavailability $\bullet$ community use $\bullet$ drug overdose $\bullet$ intramuscular $\bullet$ intranasal $\bullet$ naloxone - nasal spray • pharmacokinetics • reversal

\section{Background}

Drug poisoning is the leading cause of accidental death in the USA and is driven largely by overdose of prescription or illicit opioids [1-3]. From 2000 to 2014, the rate of opioid-related (e.g., prescription analgesics and heroin) overdose deaths tripled [2], with a further increase of 16\% observed from 2014 to 2015 [3]. A sharp increase was noted in overdose deaths related to fentanyl and fentanyl derivatives, potent synthetic opioid analgesics that can be 
manufactured or purchased illicitly [4-6]. Of 52,404 deaths caused by drug overdose in the USA in 2015, 63.1\% (33,091 deaths) involved an opioid [3].

Each year, there are more than one million emergency department visits for drug poisoning in the USA [7]. From 2008 through 2011, 14\% of emergency department visits for unintentional overdose were opioid related [7]. An analysis of the 2010 Nationwide Emergency Department Sample found that $67.8 \%$ of emergency department visits for opioid overdose involved prescription opioids, and $16.1 \%$ involved heroin $(13.4 \%$ were unspecified and $2.7 \%$ involved multiple opioid types) [8].

\section{Importance}

Since its introduction more than 40 years ago, the opioid antagonist naloxone has been used to reverse respiratory and central nervous system depression resulting from opioid overdose [9]. Until 2014, naloxone was approved by the US FDA only in injectable formulations for use by trained healthcare professionals [10]. In response to the increase in fatalities caused by opioid overdose, government agencies and community organizations have worked to establish wider access to naloxone [11-13]. Unapproved intranasal kits contain an injectable formulation of naloxone (e.g., prefilled syringe); to enable intranasal administration, the user must first attach an atomizer (manufactured by another company but provided in the kit) to the syringe [14]. Such kits have been increasingly available for public use [14] and have been employed successfully by first responders (e.g., emergency medical service personnel, police officers and bystanders) to reverse opioid overdose [15-20]. Although these products are FDA approved as injectables, they are not FDA approved for intranasal administration when included in a kit with an atomizer. Furthermore, little data have been collected on the bioavailability of naloxone when administered using these unapproved intranasal kits [14]. Importantly, human factors studies have found that many laypersons (i.e., individuals with no medical training) were unable to employ unapproved intranasal kits correctly, even after training [21,22]. For example, a prospective usability study of 42 healthy adults found that no participants $(0 \%)$ could successfully administer a dose of naloxone using an unapproved intranasal kit before training, and fewer than $60 \%$ of participants were able to successfully administer a dose of naloxone using this kit after receiving training [21].

The FDA has approved two naloxone products for use by laypersons in community settings for emergency treatment of known or suspected opioid overdose: an auto-injector for intramuscular (im.) or subcutaneous (sc.) use with a naloxone dose of 0.4 or $2 \mathrm{mg}\left(\mathrm{EVZIO}^{\circledR}\right.$; Kaléo, Inc., VA, USA) [23,24] and an intranasal spray with a concentrated naloxone dose of 2 or $4 \mathrm{mg}$ in $0.1 \mathrm{ml}$ (NARCAN ${ }^{\circledR}$; Adapt Pharma, Inc., PA, USA) [25]. The efficacy of naloxone for reversing opioid overdose is well established; therefore, FDA approval of these products was based on other data, including: compliance with good manufacturing practice requirements for combination products (drug + device) [26], human factors studies demonstrating label comprehension and ease of use [27,28] and pharmacokinetic studies demonstrating adequate bioavailability [27].

\section{Goals of this investigation}

The purpose of this systematic review is to summarize the pharmacokinetic properties of formulations of naloxone for community use (i.e., formulations currently available or in commercial development for use by laypersons for opioid overdose reversal) as a means for understanding the speed of onset, adequacy and duration of the clinical effects. With the increasing availability of highly potent synthetic opioids, the naloxone dose required to reverse opioid overdose has increased, and multiple dosing has also become common [29,30]. Consequently, the approved naloxone products and products in development offer larger naloxone doses in the devices. Therefore, it is important to evaluate the pharmacokinetic properties of these new formulations to understand their potential role in highly potent opioid overdose reversal. A secondary aim is to establish selection of optimal naloxone product based on patient-specific and product-specific factors such as route of administration, formulation and dosing considerations for community use. Community-use formulations include the im./sc. auto-injector, approved intranasal spray, unapproved intranasal kits and intranasal in-development products.

\section{Methods}

Searches of the MEDLINE and Embase ${ }^{\circledR}$ databases were conducted on 9 November 2017. Search terms included 'naloxone' and ('pharmacokinetic' OR 'pharmacokinetics'), with the dates of publication set as 2000 to present. Congress programs and abstract archives from January 2012 through October 2017 were accessed online for scientific meetings of pain medicine (American Academy of Pain Medicine and PAINWeek), addiction medicine (American Society of Addiction Medicine and Society for the Study of Addiction) and emergency medicine 
(American College of Emergency Physicians, National Association of EMS Physicians and Society for Academic Emergency Medicine) professionals. These scientific meetings were selected for review based on the authors' clinical and research expertise and the volume of material presented at these conferences relevant to the topic. Abstract and presentation titles were searched electronically for 'naloxone'. In addition, briefing documents from the 2016 FDA advisory committee meeting on naloxone and FDA product labels for naloxone products for community use were hand searched for pharmacokinetic studies not reported in other published or congress sources.

This review included original research studies that were published in English and that reported prespecified pharmacokinetic parameters for a community-use formulation of naloxone administered to either human volunteers or patients. The PRISMA guidelines checklist was followed to comply with the systematic review methodology. Prespecified pharmacokinetic variables included maximum plasma concentration $\left(\mathrm{C}_{\max } ; \mathrm{ng} / \mathrm{ml}\right)$, time to $\mathrm{C}_{\max }$ $\left(\mathrm{t}_{\max }\right.$; hours), area under the plasma concentration-time curve (AUC; $\left.\mathrm{ng} \bullet / \mathrm{h} / \mathrm{ml}\right)$, terminal elimination half-life ( $\mathrm{t}_{\frac{1}{2}}$; hours) and bioavailability (\%). $\mathrm{C}_{\max }$ and AUC assess peak and overall drug exposure, respectively. $\mathrm{T}_{\max }$ is an indicator of the speed of onset, whereas $t_{\frac{1}{2}}$ is an indicator of the duration of effect. Most studies with AUC data reported AUC from baseline extrapolated to infinity $\left(\mathrm{AUC}_{0-\infty}\right)$; therefore, $\mathrm{AUC}_{0-\infty}$ was selected as the primary assessment of total naloxone exposure. If $\mathrm{AUC}_{0-\infty}$ was not reported, $\mathrm{AUC}$ from baseline to the last measurable concentration $\left(\mathrm{AUC}_{0-\mathrm{t}}\right)$ was used. Relative bioavailability was based on $\mathrm{AUC}_{0-\infty}$ data unless otherwise specified. For the prespecified pharmacokinetic variables, measures of central tendency (mean, geometric mean and median) and variability (percent coefficient of variation, 95\% CI and range) were extracted from each study report and summarized. Pharmacokinetic variables reported in units that differed from those described above were converted as appropriate.

\section{Results}

The literature search and study selection are described in Figure 1 [24,31-37]. Seven studies were included in this review [24,31-36]. Three studies with naloxone pharmacokinetic data [38-40] were excluded because they used study-specific, investigator-compounded agents that did not represent formulations or doses currently available for community use (or in development for community use). Table 1 provides a summary of the study designs and formulations/doses used. Naloxone pharmacokinetic data were obtained from two studies of im./sc. autoinjector, one study of the approved intranasal product, two studies of unapproved intranasal kits and two studies of intranasal products in development. Results for the prespecified pharmacokinetic variables $\left(C_{\max }, t_{\max }, A U C, t_{\frac{1}{2}}\right.$ and bioavailability) from each study are shown in Table 2 [24,31-36].

\section{FDA-approved products for community use}

Naloxone pharmacokinetics for the im./sc. auto-injector were evaluated in two studies that varied with regard to the naloxone doses included. A study of 30 healthy volunteers assessed $0.4 \mathrm{mg}$ of naloxone via im./sc. auto-injector, with $0.4 \mathrm{mg}$ of naloxone im. via standard syringe and needle as the reference product [31]. Pharmacokinetic parameters of the im./sc. auto-injector and im. syringe and needle were similar for mean $C_{\max }(1.2$ and $1.1 \mathrm{ng} / \mathrm{ml}$, respectively), median $\mathrm{t}_{\max }\left(0.25\right.$ and $0.33 \mathrm{~h}$, respectively), mean $\mathrm{AUC}_{0-\infty}\left(1.9\right.$ and $2.0 \mathrm{ng} \bullet \mathrm{h} / \mathrm{ml}$, respectively) and mean $\mathrm{t}_{\frac{1}{2}}(1.3$ and $1.4 \mathrm{~h}$, respectively). The relative bioavailability of naloxone for the im./sc. auto-injector compared with im. syringe and needle was $98.3 \%$ (Table 2).

A separate study of 24 healthy volunteers evaluated $\mathrm{im}$./sc. auto-injector doses of $0.4,0.8 \mathrm{mg}$ (administered as two injections of $0.4 \mathrm{mg}$ ) and $2 \mathrm{mg}$ [24]. Mean $\mathrm{C}_{\max }$ and $\mathrm{AUC}_{0-\infty}$ were dose proportional (Table 2) [24]. Median $\mathrm{t}_{\max }$ and mean $\mathrm{t}_{\frac{1}{2}}$ were similar across doses.

Naloxone pharmacokinetics for the approved intranasal spray were evaluated at various doses ( $2 \mathrm{mg}$ [ 1 spray], $4 \mathrm{mg}$ [as 1 or 2 sprays] and $8 \mathrm{mg}$ [2 sprays]) in a study of 30 healthy volunteers, with $0.4 \mathrm{mg}$ of naloxone im. via standard syringe and needle as the reference product [32]. Mean $\mathrm{C}_{\max }$ and $\mathrm{AUC}_{0-\infty}$ were dose proportional for the approved intranasal spray (Table 2). Mean $\mathrm{C}_{\max }, \mathrm{AUC}_{0-\infty}$ and $\mathrm{t}_{\frac{1}{2}}$ were greater for all doses of the approved intranasal spray compared with the im. reference. Mean $\mathrm{C}_{\max }$ was 3.1 and $5.3 \mathrm{ng} / \mathrm{ml}$, respectively, for the approved intranasal (single spray) 2 and $4 \mathrm{mg}$, compared with $0.9 \mathrm{ng} / \mathrm{ml}$ for the im. reference (Figure 2) [32]. Mean $\mathrm{AUC}_{0-\infty}$ was 4.7 and $8.5 \mathrm{ng} \bullet / \mathrm{ml}$, respectively, for the approved intranasal (single spray) 2 and $4 \mathrm{mg}$, compared with $1.8 \mathrm{ng} \bullet \mathrm{h} / \mathrm{ml}$ for the im. reference. In addition, the mean $\mathrm{t}_{\frac{1}{2}}$ was 1.9 and $2.2 \mathrm{~h}$, respectively, for the approved intranasal (single spray) 2 and $4 \mathrm{mg}$, compared with $1.3 \mathrm{~h}$ for the im. reference. Median $\mathrm{t}_{\max }$ was generally similar for the approved intranasal spray $(0.3-0.5 \mathrm{~h})$ and im. reference $(0.4 \mathrm{~h})$. Early-stage plasma concentrations for the 4-mg dose of the approved intranasal spray relative to the im. reference are shown in Figure 3 [25]. Compared with 


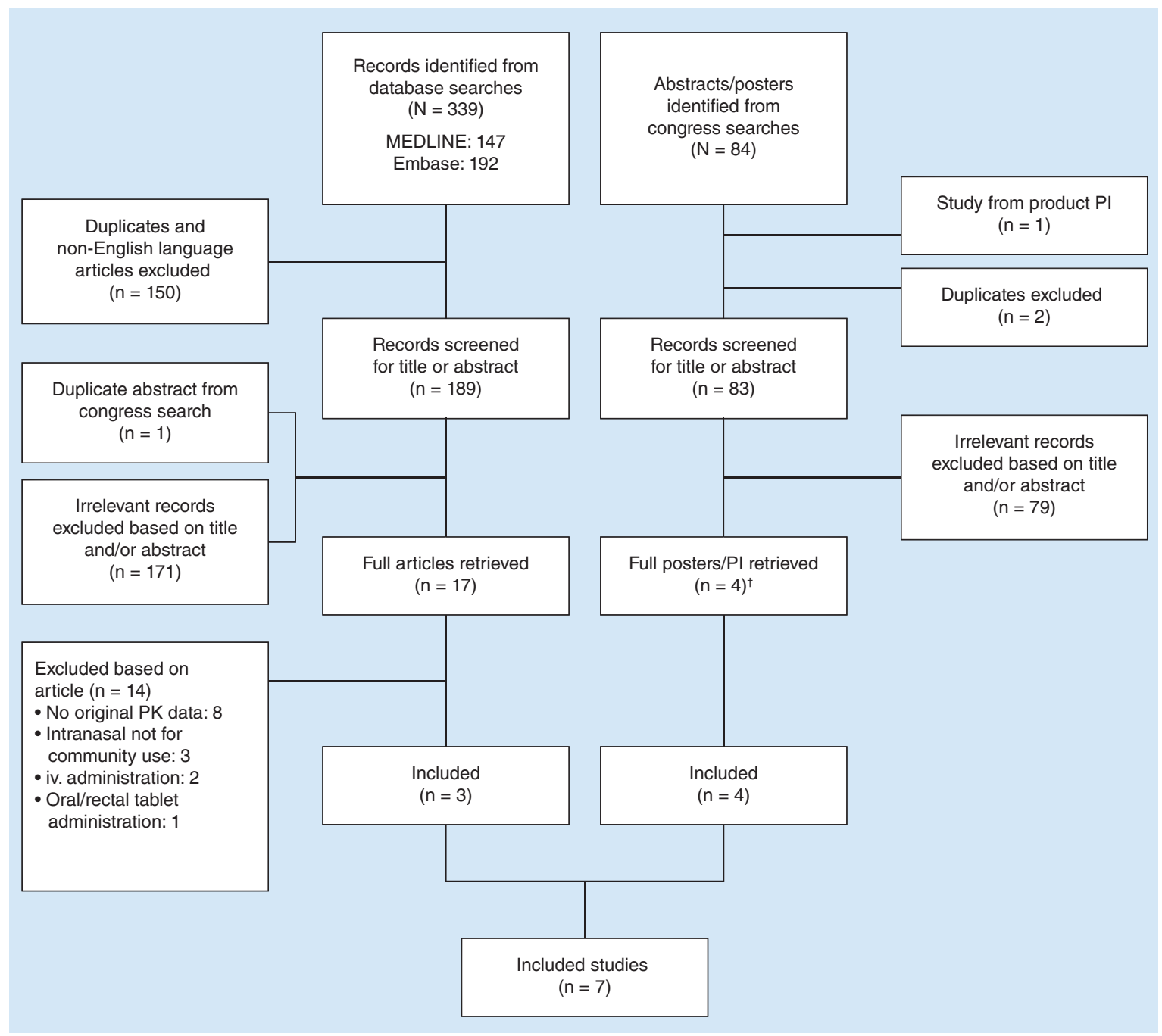

Figure 1. Flow chart of study selection.

† One study was initially included in the systematic review based on information presented as a poster [37]; however, this study was published after the search was performed [35].

iv.: Intravenous; PI: Prescribing information; PK: Pharmacokinetic.

im. administration, the relative bioavailability of naloxone for the approved intranasal spray was $51.9 \%$ for $2 \mathrm{mg}$, $46.2 \%$ for $4 \mathrm{mg}$ administered in one spray, $53.5 \%$ for $4 \mathrm{mg}$ administered in two sprays of $2 \mathrm{mg}$ and $43.9 \%$ for $8 \mathrm{mg}$ (administered in two sprays of $4 \mathrm{mg}$ ).

\section{Unapproved intranasal kits}

A study of 36 adults with chronic rhinitis assessed a commercially available, unapproved intranasal kit (2-mg naloxone as $1 \mathrm{mg} / \mathrm{ml}$ in each nostril) compared with $2-\mathrm{mg}$ im. $(1 \mathrm{mg} / \mathrm{ml}$ in each thigh via standard needle and syringe) [33]. $\mathrm{C}_{\max }$ and $\mathrm{AUC}_{0-\infty}$ were lower for the unapproved intranasal kit compared with the 2-mg im. (mean $\mathrm{C}_{\max }$ of 1.3 vs $4.5 \mathrm{ng} / \mathrm{ml}$, respectively; mean $\mathrm{AUC}_{0-\infty}$ of 1.5 vs $9.8 \mathrm{ng} \bullet \mathrm{h} / \mathrm{ml}$, respectively) (Table 2) [33]; however, the im. reference dose was five-times greater than that used in other pharmacokinetic studies [31,32,35]. For both formulations, median $\mathrm{t}_{\max }(0.25 \mathrm{~h})$ and mean $\mathrm{t}_{\frac{1}{2}}(1.5 \mathrm{~h})$ were similar. Relative bioavailability (which takes dose into account) was $14.6 \%$ for the unapproved intranasal compared with im. naloxone. The use of an intranasal vasoconstrictor (30 min prior) reduced the naloxone exposure obtained using the unapproved intranasal kit (Table 2).

A study of six volunteers used a population-pharmacokinetic modeling and simulation approach to evaluate unapproved intranasal, im. and intravenous (iv.) delivery of naloxone (commercially available, $0.4 \mathrm{mg} / \mathrm{ml}$ ) [34]. 


\begin{tabular}{|c|c|c|c|c|c|c|}
\hline $\begin{array}{l}\text { Naloxone } \\
\text { formulation }\end{array}$ & Study (year) & Naloxone dose(s) & Comparator product(s) & Study design & $\mathbf{N}$ & Ref. \\
\hline \multicolumn{7}{|c|}{ US FDA-approved formulations for community use } \\
\hline $\begin{array}{l}\text { im./sc. auto-injector } \\
\left(\mathrm{EVZIO}^{\circledR}\right)\end{array}$ & Edwards et al. (2015) & $\begin{array}{l}0.4 \mathrm{mg} \text { (midanterolateral } \\
\text { thigh) }\end{array}$ & $\begin{array}{l}0.4-\mathrm{mg} \text { im. standard } \\
\text { syringe and needle } \\
\text { (midanterolateral thigh) }\end{array}$ & $\begin{array}{l}\mathrm{R} \text {, single-blind, } \\
\text { single-dose, 2-period, } \\
\text { 2-sequence, crossover }\end{array}$ & $\begin{array}{l}30 \text { healthy adult } \\
\text { volunteers }\end{array}$ & [31] \\
\hline $\begin{array}{l}\text { im./sc. auto-injector } \\
\left(\mathrm{EVZIO}^{\circledR}\right)\end{array}$ & Product PI & $\begin{array}{l}0.4 \mathrm{mg} \text { ( } 1 \text { injection) } \\
0.8 \mathrm{mg} \text { ( } 2 \text { injections of } \\
0.4 \mathrm{mg} \text { administered } 2 \mathrm{~min} \\
\text { apart) } \\
2 \mathrm{mg} \text { ( } 1 \text { injection) }\end{array}$ & - & $\begin{array}{l}\text { Crossover (other design } \\
\text { details not specified) }\end{array}$ & $\begin{array}{l}24 \text { healthy volunteers } \\
\text { (age not specified) }\end{array}$ & {$[24]$} \\
\hline $\begin{array}{l}\text { Approved intranasal } \\
\left(\text { NARCAN }^{\circledR}\right)\end{array}$ & Krieter et al. (2016) & $\begin{array}{l}2 \mathrm{mg} \text { ( } 1 \text { spray of } \\
2 \mathrm{mg} / 0.1 \mathrm{ml}) \\
4 \mathrm{mg}(1 \mathrm{spray} \text { of } \\
4 \mathrm{mg} / 0.1 \mathrm{ml}) \\
4 \mathrm{mg}(1 \mathrm{spray} \text { of } \\
2 \mathrm{mg} / 0.1 \mathrm{ml} \text { in each } \\
\text { nostril) } \\
8 \mathrm{mg}(1 \text { spray of } \\
4 \mathrm{mg} / 0.1 \mathrm{ml} \text { in each } \\
\text { nostril) }\end{array}$ & $\begin{array}{l}0.4-\mathrm{mg} \text { im. standard } \\
\text { syringe and needle } \\
(0.4 \mathrm{mg} / 1 \mathrm{ml} \text {, gluteus } \\
\text { maximus) }\end{array}$ & $\begin{array}{l}\mathrm{R}, \mathrm{OL}, 5 \text {-period, } \\
\text { 5-treatment, } \\
\text { 5-sequence, crossover }\end{array}$ & $\begin{array}{l}30 \text { healthy adult } \\
\text { volunteers }\end{array}$ & [32] \\
\hline \multicolumn{7}{|c|}{ Unapproved intranasal kits } \\
\hline $\begin{array}{l}\text { Unapproved } \\
\text { intranasal }\left(\mathrm{LMA}^{\circledR}\right. \\
\left.\text { MAD Nasal }^{\text {TM }}\right)^{\dagger}\end{array}$ & Edwards et al. (2016) & $\begin{array}{l}2 \mathrm{mg}(1 \mathrm{mg} / \mathrm{ml} \text { in each } \\
\text { nostril) }\end{array}$ & $\begin{array}{l}\text { 2-mg im. standard syringe } \\
\text { and needle ( } 1 \mathrm{mg} / 1 \mathrm{ml} \text { in } \\
\text { each thigh) }\end{array}$ & $\begin{array}{l}\mathrm{R}, \mathrm{OL} \text {, single-dose, } \\
\text { 3-period, crossover }\end{array}$ & $\begin{array}{l}36 \text { adults with chronic } \\
\text { rhinitis but no } \\
\text { significant nasal } \\
\text { abnormalities, surgery, } \\
\text { polyps or trauma }\end{array}$ & [33] \\
\hline $\begin{array}{l}\text { Unapproved } \\
\text { intranasal }(M A D)^{\ddagger}\end{array}$ & Dowling et al. (2008) & $\begin{array}{l}0.8 \mathrm{mg} \text { ( } 1 \text { spray of } \\
0.4 \mathrm{mg} / 1 \mathrm{ml} \text { in each } \\
\text { nostril) } \\
2 \mathrm{mg} \mathrm{(1} \mathrm{spray} \mathrm{of} 1 \mathrm{mg} / \\
2.5 \mathrm{ml} \text { in each nostril) }\end{array}$ & $\begin{array}{l}0.8-\mathrm{mg} \text { iv. } \\
2 \text {-mg iv. } \\
0.8-\mathrm{mg} \text { im. standard } \\
\text { syringe and needle } \\
\text { (gluteus maximus) }\end{array}$ & OL, crossover & $\begin{array}{l}6 \text { healthy adult } \\
\text { volunteers }\end{array}$ & [34] \\
\hline \multicolumn{7}{|c|}{ Community-use formulations in development } \\
\hline $\begin{array}{l}\text { Intranasal in } \\
\text { development } \\
\text { (Mundipharma) }\end{array}$ & $\begin{array}{l}\text { McDonald et al. } \\
(2017)\end{array}$ & $\begin{array}{l}1 \mathrm{mg}(1 \mathrm{spray} \text { of } \\
1 \mathrm{mg} / 0.1 \mathrm{ml}) \\
2 \mathrm{mg}(1 \mathrm{spray} \text { of } \\
2 \mathrm{mg} / 0.1 \mathrm{ml}) \\
4 \mathrm{mg}(2 \mathrm{sprays} \text { of } \\
2 \mathrm{mg} / 0.1 \mathrm{ml})\end{array}$ & $\begin{array}{l}\text { 0.4-mg im. standard } \\
\text { syringe and needle } \\
\text { (primary reference; } \\
\text { deltoid muscle) } \\
\text { 0.4-mg iv. }\end{array}$ & R, OL, 5-way, crossover & $\begin{array}{l}38 \text { healthy adult } \\
\text { volunteers }\end{array}$ & [35] \\
\hline $\begin{array}{l}\text { Intranasal in } \\
\text { development (dne } \\
\text { pharma) }\end{array}$ & Tylleskar et al. (2017) & $\begin{array}{l}0.8 \mathrm{mg} \text { (1 spray of } \\
0.8 \mathrm{mg} / 0.1 \mathrm{ml}) \\
1.6 \mathrm{mg}(2 \mathrm{sprays} \text { of } \\
0.8 \mathrm{mg} / 0.1 \mathrm{ml})\end{array}$ & $1.0-\mathrm{mg}$ iv. & R, OL, 3-way crossover & $\begin{array}{l}12 \text { healthy adult } \\
\text { volunteers }\end{array}$ & [36] \\
\hline
\end{tabular}

Pharmacokinetic parameters were not reported separately for each formulation, with the exception of relative bioavailability (derived from the modeling/simulation), which was $4 \%$ for unapproved intranasal compared with iv. administration. The relative bioavailability of im. versus iv. administration was $36 \%$.

\section{Community-use formulations in development}

Naloxone pharmacokinetics for the two intranasal products in development were evaluated in one study each. A study of 38 healthy volunteers assessed an intranasal spray (Mundipharma) at doses of 1,2 and $4 \mathrm{mg}$, with $0.4 \mathrm{mg}$ of naloxone im. via standard syringe and needle as the primary reference product (and also 0.4-mg iv. naloxone) [35]. Geometric mean $\mathrm{C}_{\max }$ was $2.9 \mathrm{ng} / \mathrm{ml}$ for the $2-\mathrm{mg}$ intranasal in-development product compared with $1.3 \mathrm{ng} / \mathrm{ml}$

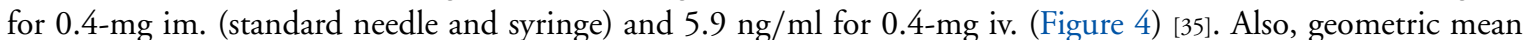
$\mathrm{AUC}_{0-\infty}$ was $5.0 \mathrm{ng} \bullet \mathrm{h} / \mathrm{ml}$ for the $2-\mathrm{mg}$ intranasal in-development product compared with $2.1 \mathrm{ng} \bullet / \mathrm{ml}$ for both the $0.4-\mathrm{mg}$ im. (standard needle and syringe) and the $0.4-\mathrm{mg}$ iv. product. Median $\mathrm{t}_{\mathrm{max}}$ was somewhat longer for the 2 -mg intranasal in-development product $(0.5 \mathrm{~h})$ compared with $0.4-\mathrm{mg} \mathrm{im} .(0.2 \mathrm{~h})$ naloxone; whereas, mean $\mathrm{t}_{\frac{1}{2}}$ was similar (1.4 h for both). Early-stage plasma concentrations for the intranasal in-development product relative 
Table 2. Pharmacokinetic parameters for community-use formulations of naloxone.

\begin{tabular}{|c|c|c|c|c|c|c|}
\hline Naloxone formulation & $\mathbf{N}$ & $\begin{array}{l}\text { Mean }(\% \mathrm{CV}) \mathrm{C}_{\max } \\
\mathrm{ng} / \mathrm{ml}\end{array}$ & $\begin{array}{l}\text { Mean (\%CV) } \\
\mathrm{AUC}_{0-\infty}, \mathrm{ng} \bullet \mathrm{h} / \mathrm{ml}\end{array}$ & Median (range) $t_{\max }, h$ & Mean $(\% C V) t_{1 / 2}, h$ & Bioavailability, \% \\
\hline \multicolumn{7}{|c|}{ US FDA-approved formulations for community use } \\
\hline \multicolumn{7}{|l|}{ im./sc. auto-injector naloxone } \\
\hline 0.4-mg dose [31] & 30 & $1.2(51.4)$ & $1.9(23.4)$ & $0.25(0.08-1.23)$ & $1.3(38.0)$ & $98.3^{\dagger}$ \\
\hline 0.4-mg dose [24] & 24 & $1.3(62.9)$ & $2.0(16.3)$ & $0.25(0.09-0.84)$ & $1.6(28.9)$ & NA \\
\hline 0.8-mg (two 0.4-mg) dose [24] & 24 & $2.2(47.4)$ & $3.8(19.1)$ & $0.21(0.09-0.85)$ & $1.5(23.7)$ & NA \\
\hline 2-mg dose [24] & 24 & $7.9(45.8)$ & $10.3(15.2)$ & $0.25(0.13-0.67)$ & $1.5(25.0)$ & NA \\
\hline \multicolumn{7}{|l|}{ Approved intranasal spray [32] } \\
\hline $2 \mathrm{mg}$ (1 spray of $2 \mathrm{mg} / 0.1 \mathrm{ml}$ ) & 29 & $3.1(36.1)$ & $4.7(29.8)$ & $0.3(0.3-1.0)$ & $1.9(34.6)$ & $51.9^{\dagger}$ \\
\hline $4 \mathrm{mg}$ (1 spray of $4 \mathrm{mg} / 0.1 \mathrm{ml}$ ) & 29 & $5.3(44.6)$ & $8.5(39.0)$ & $0.5(0.2-1.0)$ & $2.2(29.1)$ & $46.2^{\dagger}$ \\
\hline $4 \mathrm{mg}$ (2 sprays of $2 \mathrm{mg} / 0.1 \mathrm{ml}$ ) & 29 & $6.5(32.3)$ & $9.7(26.7)$ & $0.3(0.2-0.6)$ & $2.4(31.7)$ & $53.5^{\dagger}$ \\
\hline $8 \mathrm{mg}$ (2 sprays of $4 \mathrm{mg} / 0.1 \mathrm{ml}$ ) & 29 & $10.3(38.1)$ & $15.8(23.1)$ & $0.3(0.2-1.0)$ & $2.2(39.0)$ & $43.9^{\dagger}$ \\
\hline \multicolumn{7}{|l|}{ Unapproved intranasal kits } \\
\hline \multicolumn{7}{|l|}{ Unapproved intranasal [33] } \\
\hline $2 \mathrm{mg} / 2 \mathrm{ml} \ddagger$ & $36^{\S}$ & $1.3(48.3)$ & $1.5(31.6)$ & $0.25(0.07-0.68)$ & $1.5(18.5)$ & $14.6 \mathbb{I}$ \\
\hline $2 \mathrm{mg} / 2 \mathrm{ml} \ddagger+$ vasoconstrictor\# & $36^{\S}$ & $0.7(52.0)$ & $1.1(35.1)$ & $0.33(0.08-1.00)$ & $1.5(22.9)$ & $11.1 \mathbb{I}$ \\
\hline \multicolumn{7}{|c|}{ Community-use formulations in development } \\
\hline \multicolumn{7}{|c|}{ Intranasal in development (Mundipharma) [35] } \\
\hline $1 \mathrm{mg}$ (1 spray of $1 \mathrm{mg} / 0.1 \mathrm{ml})$ & 32 & $1.5^{\dagger \dagger}(50.2)$ & $2.7^{\dagger \dagger}(40.5)$ & $0.25(0.2-1.0)$ & 1.3 (NA) & $50.8^{\dagger}$ \\
\hline $2 \mathrm{mg}$ ( 1 spray of $2 \mathrm{mg} / 0.1 \mathrm{ml}$ ) & 32 & $2.9^{\dagger \dagger}(49.6)$ & $5.0^{\dagger \dagger}(38.5)$ & $0.5(0.1-1.0)$ & 1.4 (NA) & $47.1^{\dagger}$ \\
\hline $4 \mathrm{mg}$ (2 sprays of $2 \mathrm{mg} / 0.1 \mathrm{ml}$ ) & 32 & $6.0^{\dagger \dagger}(54.5)$ & $10.1^{\dagger \dagger}(35.8)$ & $0.25(0.2-1.0)$ & 1.7 (NA) & $48.3^{\dagger}$ \\
\hline \multicolumn{7}{|c|}{ Intranasal in development (dne pharma) [36] } \\
\hline $0.8 \mathrm{mg}$ (1 spray of $0.8 \mathrm{mg} / \mathrm{ml}$ ) & 12 & $1.4(1.1-1.8)^{\ddagger \ddagger}$ & $1.6(1.3-2.0)^{\ddagger \ddagger \S \S}$ & $0.3(0.2-0.4)^{\dagger \dagger}$ & $1.5(1.3-1.7)^{\dagger \dagger}$ & $54 \mathbb{I}$ \\
\hline $1.6 \mathrm{mg}$ (2 sprays of $0.8 \mathrm{mg} / \mathrm{ml}$ ) & 11 & $2.6(1.5-3.7)^{\ddagger \ddagger}$ & $3.1(2.0-4.1)^{\ddagger \ddagger \S \S}$ & $0.3(0.2-0.4)^{\dagger \dagger}$ & $1.3(1.1-1.5)^{\dagger \dagger}$ & $52 \mathbb{I}$ \\
\hline \multicolumn{7}{|c|}{ 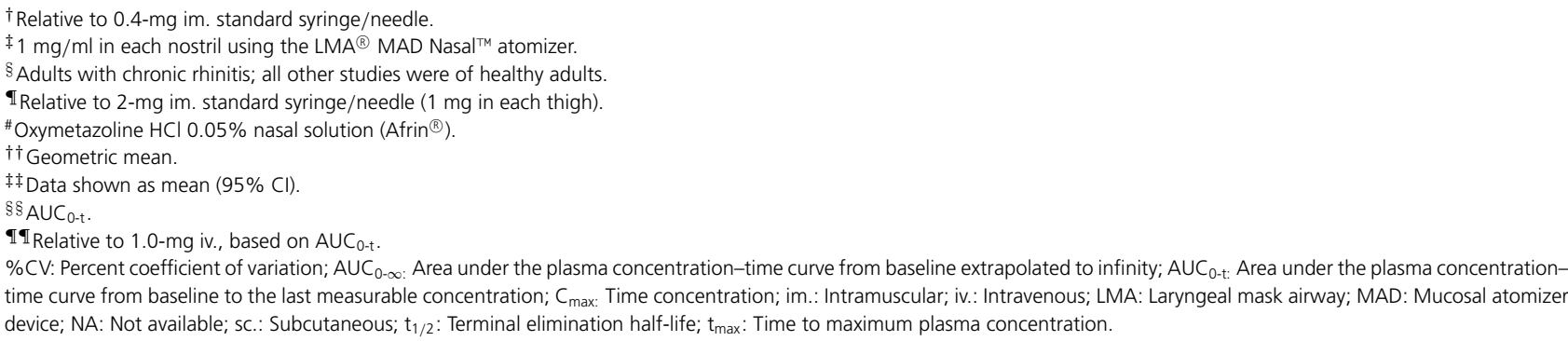 } \\
\hline
\end{tabular}

to the iv. and im. reference products are shown in Figure 5. Compared with im. administration, the bioavailability for intranasal in-development naloxone was $50.8 \%$ for $1 \mathrm{mg}$, $47.1 \%$ for $2 \mathrm{mg}$ and $48.3 \%$ for $4 \mathrm{mg}$ (administered as two sprays of $2 \mathrm{mg}$ ).

A different intranasal in-development product (manufactured by dne pharma) was assessed in 12 healthy volunteers; naloxone doses were 0.8 and $1.6 \mathrm{mg}$ ( 2 sprays of $0.8 \mathrm{mg}$ ), with $1.0-\mathrm{mg}$ iv. naloxone as the reference product [36]. Mean $\mathrm{C}_{\max }$ was $2.6 \mathrm{ng} / \mathrm{ml}$ for the 1.6- $\mathrm{mg}$ intranasal in-development product compared with $14.2 \mathrm{ng} / \mathrm{ml}$ for iv. administration (Figure 6) [36]. Mean $\mathrm{AUC}_{0-\mathrm{t}}$ was $3.1 \mathrm{ng} \bullet \mathrm{h} / \mathrm{ml}$ for intranasal in-development product $1.6 \mathrm{mg}$ compared with $4.0 \mathrm{ng} / \mathrm{ml}$ for $1.0 \mathrm{mg}$ iv. Mean $\mathrm{t}_{\max }$ was longer for intranasal in-development product $1.6 \mathrm{mg}(0.3$ h) compared with iv. $(0.04 \mathrm{~h})$ naloxone; whereas, mean $\mathrm{t}_{\frac{1}{2}}$ was similar (1.3 and $1.2 \mathrm{~h}$, respectively). Compared with iv. administration, the bioavailability for the intranasal in-development naloxone was $54 \%$ for the 0.8 -mg dose and $52 \%$ for the $1.6-\mathrm{mg}$ dose.

\section{Discussion}

Two naloxone products for community use have been approved by the FDA for emergency treatment of known or suspected opioid overdose, based on pharmacokinetic and human factors studies: an im./sc. auto-injector and a concentrated naloxone dose via an intranasal spray (no device assembly required) [23-25]. In the absence of headto-head, comparative efficacy studies in the community-use setting, which are not feasible for ethical and logistical 


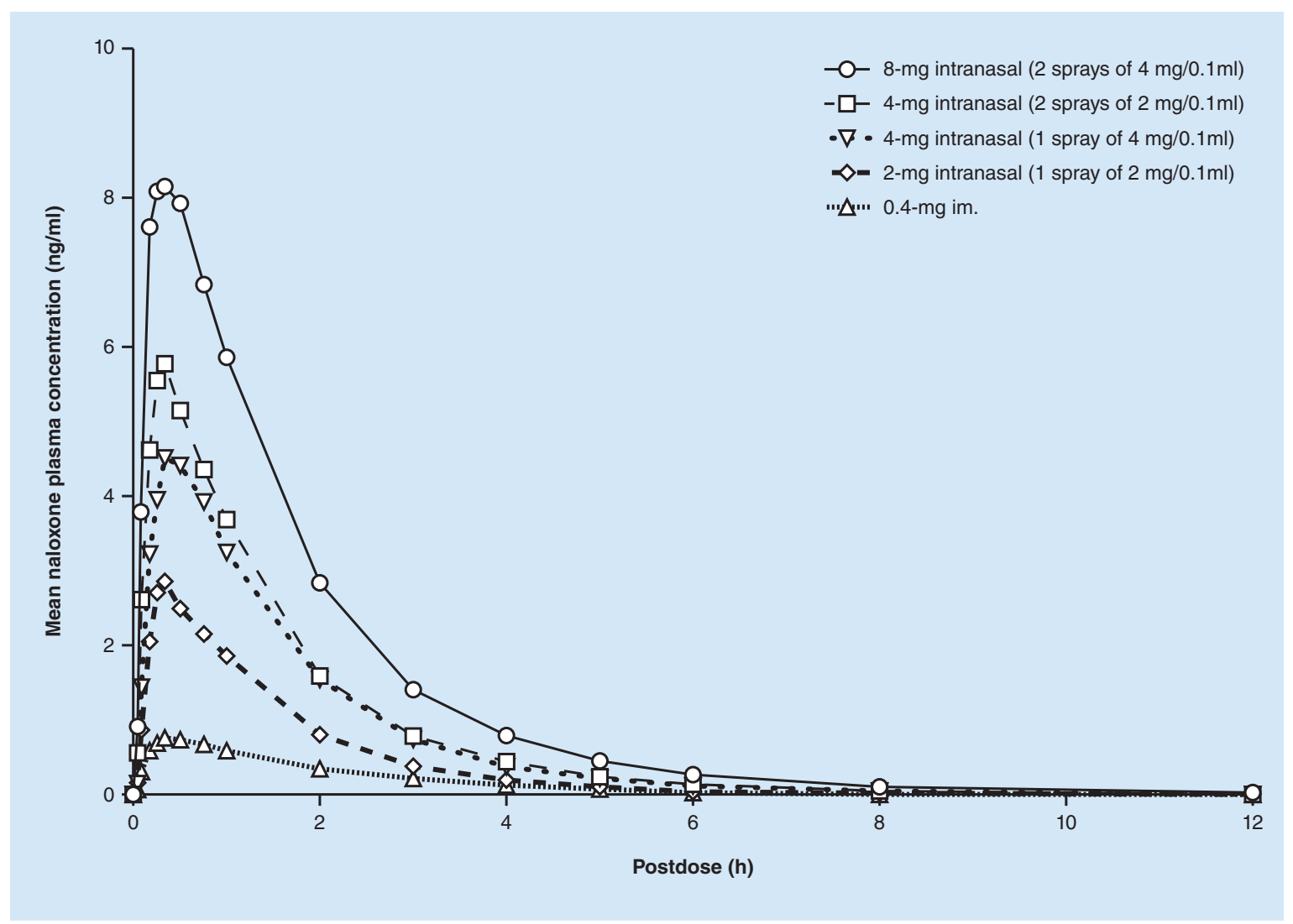

Figure 2. Mean naloxone plasma concentration-time curves for approved intranasal spray versus intramuscular standard syringe: overall.

im.: Intramuscular.

Reprinted with permission from [32] ๔ John Wiley \& Sons, Inc. (2016).

reasons, pharmacokinetic data provide important information about effective doses and routes of administration of naloxone for opioid overdose reversal.

In pharmacokinetic studies, both the im./sc. auto-injector and the approved intranasal spray demonstrated bioequivalence with a previously approved formulation, indicating that naloxone exposure was adequate to reverse an opioid overdose [31,32]. By contrast, unapproved intranasal kits (syringe with atomizer attachment) using a commercially available naloxone solution intended for iv. use $(0.4 \mathrm{mg} / \mathrm{ml}, 2 \mathrm{mg} / 2 \mathrm{ml}$ [predominantly used] $)$ have shown low bioavailability of naloxone relative to iv. (4\%) [34] or im. (15\%) [33] administration; additionally, the unapproved kits lack the label comprehension or human-use study data needed for FDA approval of a combination drug/device product. The poor bioavailability for the unapproved intranasal kits is likely related to the large volume of the solution that has to be atomized and absorbed in the nasal cavity, which may result in a loss of naloxone from the site of absorption (via drainage, either into the nasopharynx or externally) [41,42]. As a consequence of nasopharyngeal drainage, intranasal administration of a large volume of solution fails to bypass the extensive first-pass metabolism associated with oral administration of naloxone [43]. The approved intranasal spray addresses this issue by using a highly concentrated solution of naloxone such that the volume of each spray is only $0.1 \mathrm{ml}$ [25]. Consistently, an explorative review integrating patent application data for noninjectable naloxone for opioid overdose and scientific publications reported that bioavailability of intranasal naloxone products has a positive association with dose and negative association with volume [44]. Although there are concerns of overantagonism with higher doses of naloxone resulting in severe withdrawal symptoms $[45,46]$, the risk of inadequate reversal, especially with overdose of potent opioids such as fentanyl, is far greater than the risk of unpleasant opioid withdrawal reactions [46]. No studies have yet assessed the initial dose of naloxone required to reverse a fentanyl-related overdose.

Rapid uptake of naloxone is critically important because opioid overdose may result in respiratory depression with hypoxia, which leads to cardiopulmonary arrest and long-term damage to the central nervous system or 


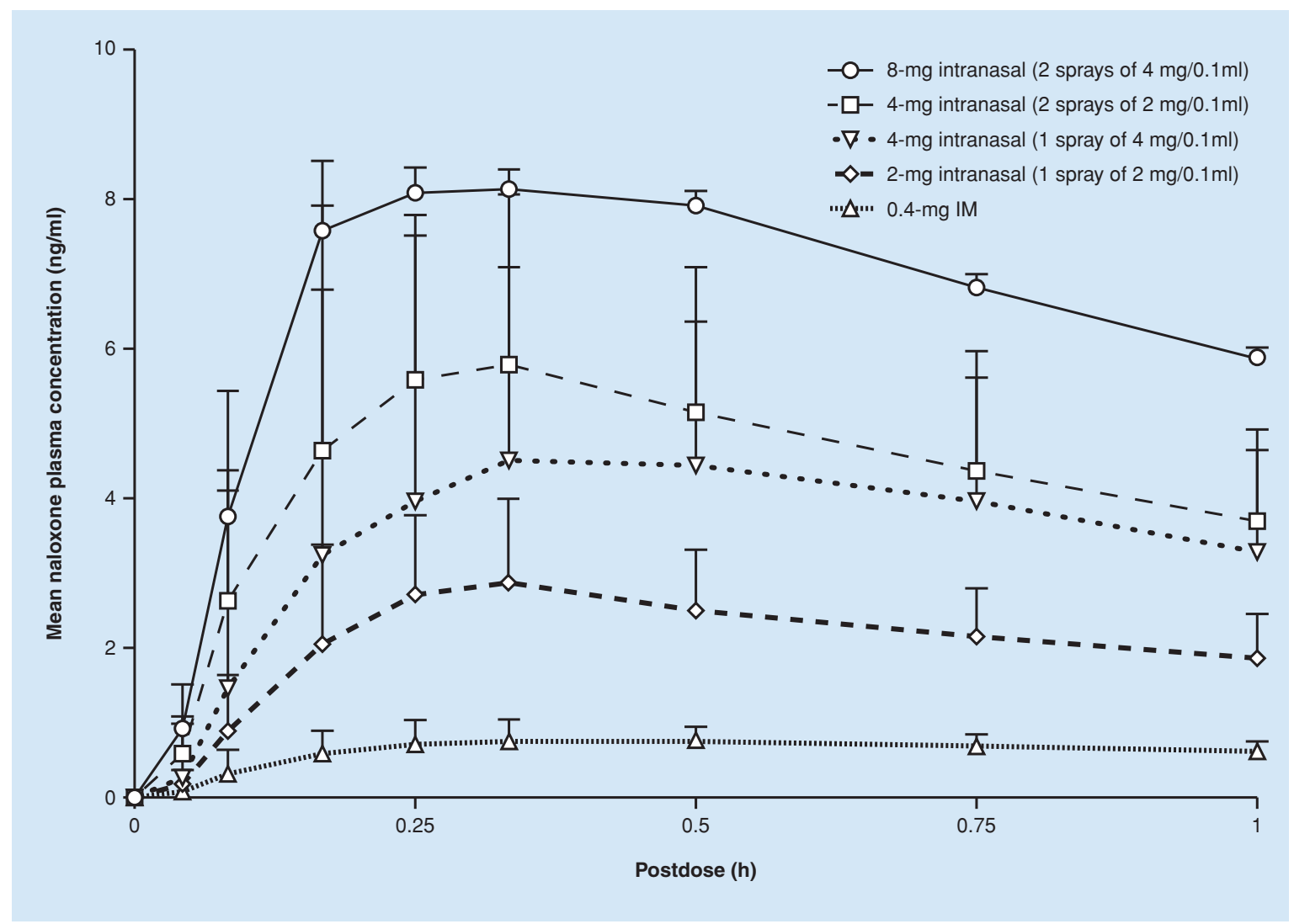

Figure 3. Mean naloxone plasma concentration-time curves for approved intranasal spray versus intramuscular standard syringe: early-stage (0-1 h).

Error bars represent standard deviation.

im.: Intramuscular.

Reprinted with permission from [25] (c) Adapt Pharma, Inc. (2017).

death [47]. The need for both rapid onset and adequate duration of the naloxone effect is especially significant in light of the increase in overdose deaths involving high-potency, synthetic opioids [2-4]. Both the im./sc. autoinjector and the approved intranasal spray demonstrated sufficient plasma exposure within the first 15-20 min after administration to garner FDA approval. By contrast, a different intranasal spray was denied approval, potentially because of inadequate early-stage uptake of naloxone [48]. The duration of action is shorter for naloxone compared with most opioids; additional dose(s) may be required if the initial response is inadequate or if signs of overdose (e.g., respiratory depression) recur $[23,25,27,49]$.

The optimal naloxone dose is one that successfully reverses opioid overdose without precipitating acute withdrawal symptoms [50]. However, most of the information necessary to make a precise dose determination (e.g., mu receptor affinity of the opioid taken and dose taken) is unavailable at the time that naloxone is administered, and varying naloxone dosing algorithms have been suggested $[43,49,50]$. The recent increase in overdose deaths related to potent opioids such as fentanyl [4] has tipped the balance toward the need for adequately high naloxone doses to prevent overdose fatalities. The FDA stance on naloxone dosing is evident in the approval of a new, higher dose $(2 \mathrm{mg})$ for the im./sc. naloxone injector and a limited indication for the lower dose $(2 \mathrm{mg})$ of intranasal naloxone (only for opioid-dependent patients expected to be at risk for severe opioid withdrawal [assuming this information is known at the time of naloxone administration]). The higher dose of the im./sc. auto-injector was developed to ensure that adequate naloxone would be provided for reversing overdose of various types of opioids, including potent opioids such as fentanyl [24]. In fact, an FDA advisory committee voted in 2016 to increase the current pharmacokinetic benchmark $(0.4-\mathrm{mg} \mathrm{im}$.) for approval of naloxone products for community use $[51,52]$. The makers of the im./sc. auto-injector intend to discontinue manufacturing the lower $(0.4-\mathrm{mg})$ dose [53]. 


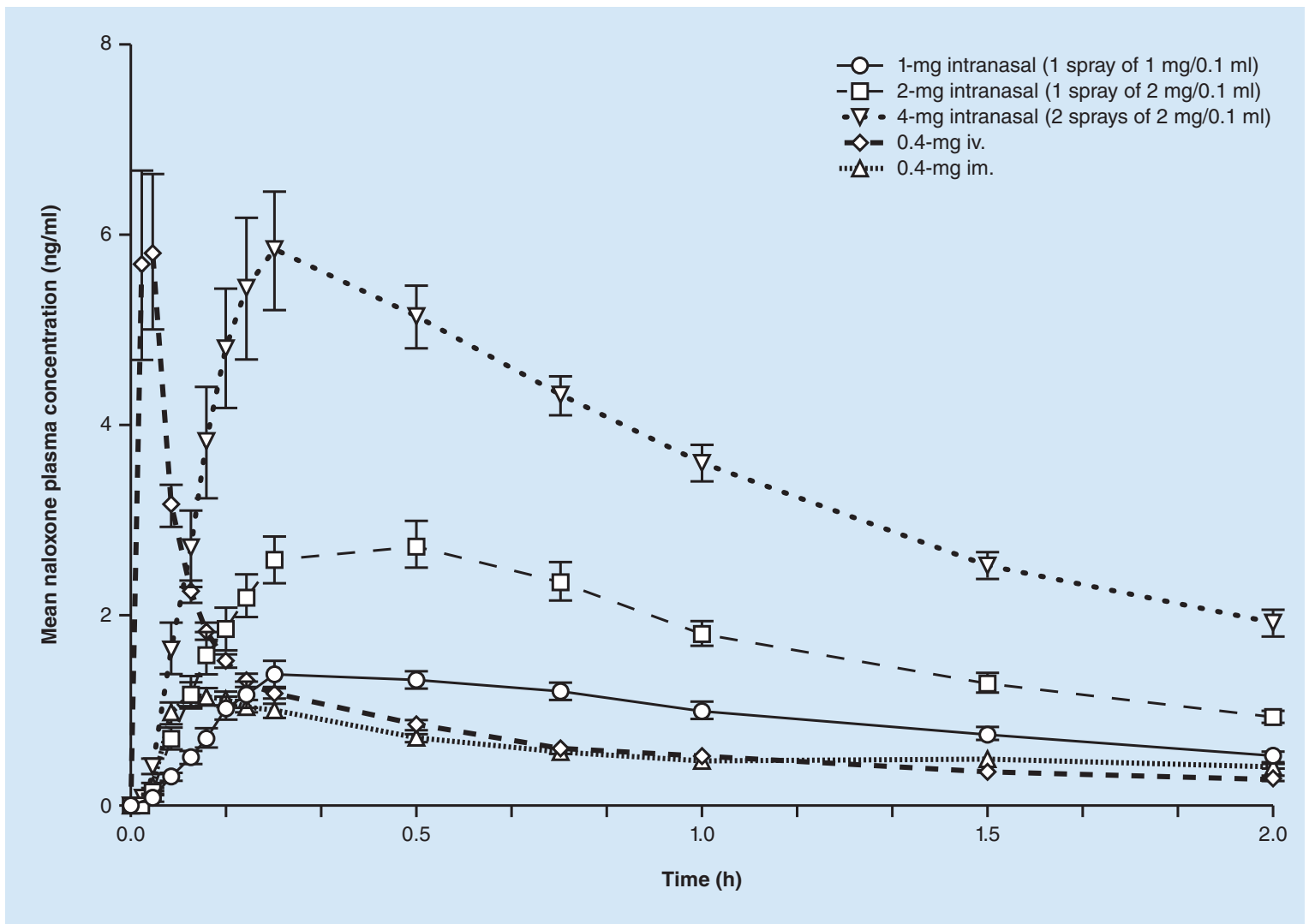

Figure 4. Mean naloxone plasma concentration-time curves for intranasal formulation in-development, intramuscular standard syringe and intravenous administration: overall ( $2 \mathrm{~h}$ ).

Error bars represent standard deviation.

im.: Intramuscular; iv.: Intravenous.

Adapted with permission from [35] (2018) via a CreativeCommons Attribution-NonCommercial license.

Approved intranasal spray initially received FDA approval in 2015 at a dose of $4 \mathrm{mg}$. A concentrated solution $(4 \mathrm{mg} / 0.1 \mathrm{ml})$ is used for optimal absorption in the nasal cavity, with repeat dosing available if necessary [25]. The recently approved 2-mg dose of approved intranasal spray has a restriction in the 'Indications for Use' section of the label that limits its use to a specific patient population under particular circumstances. Specifically, use of the 2-mg dose is restricted to "opioid-dependent patients expected to be at risk for severe opioid withdrawal in situations where there is a low risk for accidental or intentional opioid exposure by household contacts" [25]. In practice, the lower (2-mg) dose of the approved intranasal spray provides a dosing alternative for patients in whom there are concerns about precipitating severe opioid withdrawal living in situations where the lower dose of naloxone will not put other members of the household at risk for opioid overdose [54]. The intranasal products in development appear highly similar in both formulation (high concentration and low volume) and device to the approved intranasal spray $[32,35,36]$.

Although comparative efficacy studies of naloxone formulations in the community-use setting are not feasible, the use of unapproved intranasal naloxone spray in a prehospital setting has been shown to be effective in reversing opioid overdose in retrospective studies [17,19], prospective nonrandomized studies $[15,18,20]$ and in a randomized controlled study with im. naloxone as a comparator treatment arm [16]. A recent survey of first responders and community-based organizations assessing the initial real-world experience of the approved $4 \mathrm{mg}$ intranasal naloxone spray reported successful reversal of opioid overdose in $98.8 \%$ of the cases [55].

In addition to efficacy, usability is a vital characteristic for community-use formulations of naloxone, which are expected to be used by laypersons in highly stressful situations. Studies have identified critical errors with the proper assembly and use of unapproved intranasal kits by laypersons in simulated overdose conditions, even when training had been provided [21,22]. However, human factors studies have found that more than $90 \%$ of participants were 


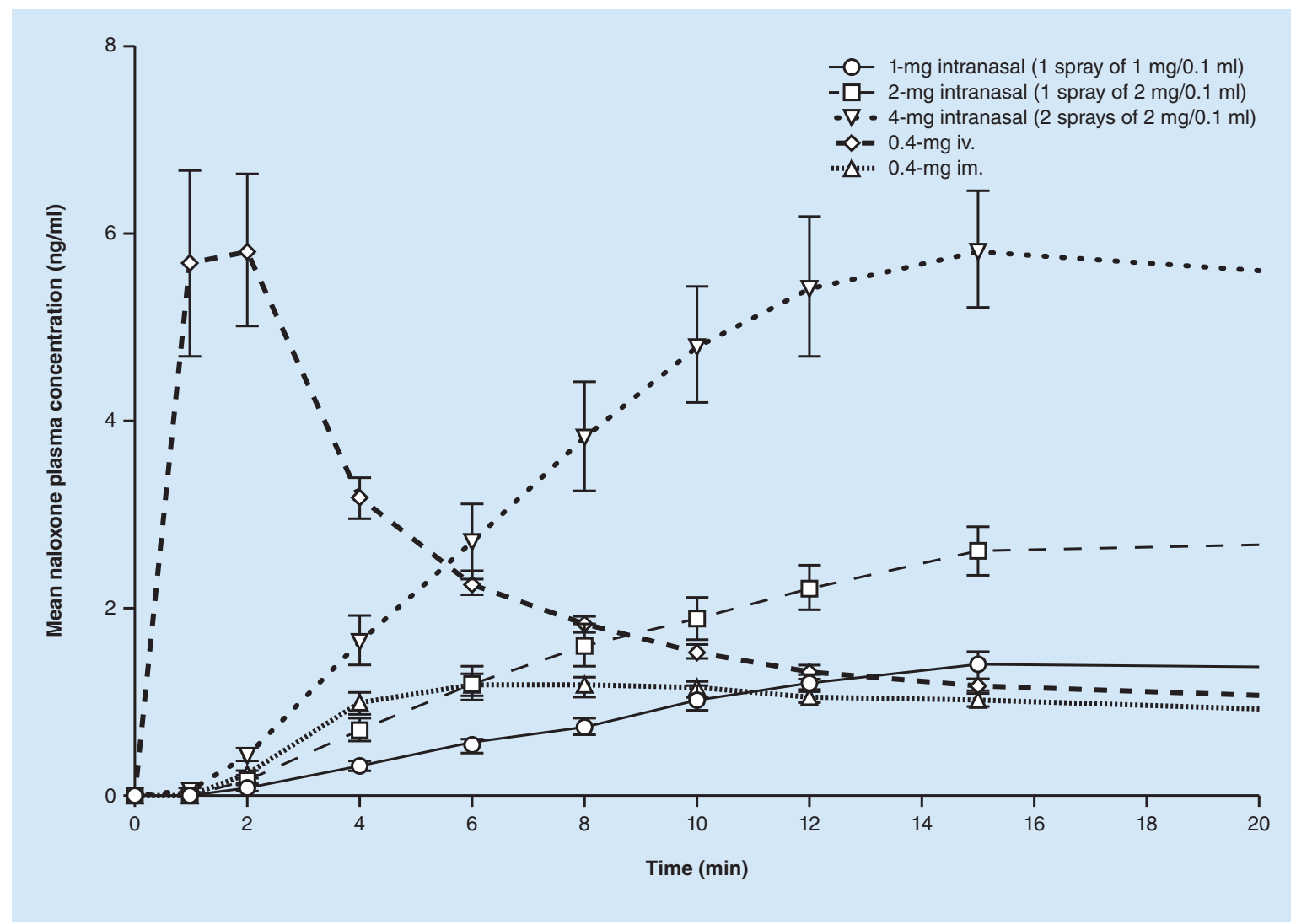

Figure 5. Mean naloxone plasma concentration-time curves for intranasal formulation in-development, intramuscular standard syringe and intravenous administration: early stage (20 min).

Error bars represent standard deviation.

im.: Intramuscular; iv.: Intravenous.

Adapted with permission from [35] (2018) via a CreativeCommons Attribution-NonCommercial license.

able to successfully administer naloxone using the im./sc. auto-injector [21,22] or the approved intranasal spray [32] without prior training.

A study conducted at an urban hospital in Canada evaluated an emergency-department-based take-home naloxone program for patients at the risk of opioid overdose [56]. Of 201 participants, 68.2\% accepted an unapproved intranasal kit and training. Since $92 \%$ of participants believed that take-home naloxone was 'a good idea', acceptance would likely be greater for an FDA-approved product that can be used successfully without training (instead, a brief explanation should be provided and recipients of the product should be encouraged to read the instructions for use thoroughly). Prescription of approved naloxone products also may reduce the training burden on pharmacists, since the counseling required by standing naloxone protocols in effect at pharmacies in many states is simpler for approved products than for unapproved intranasal kits [57-59].

\section{Clinical implications}

Providing prescriptions for community-use naloxone to patients at risk of opioid overdose (prescribed opioids or illicit use) may help reduce the number of opioid-related fatalities [56]. A prescription for community-use naloxone may be particularly appropriate for patients receiving daily opioid therapy for chronic pain and for patients who are known (or suspected) users of illicit opioids, based on self-report or observed signs and symptoms. For patients on daily opioid therapy, guidelines from the Centers for Disease Control and Prevention suggest a dose threshold of concern at 50 morphine milligram equivalents (MME) per day [60]. Specifically, the guidelines state "Clinicians should use caution when prescribing opioids at any dosage, should carefully reassess evidence of individual benefits and risks when considering increasing dosage to $50 \mathrm{MME}$ or more per day and should avoid increasing dosage to $90 \mathrm{MME}$ or more per day or carefully justify a decision to titrate dosage to $90 \mathrm{MME}$ or more per day" [60]. 


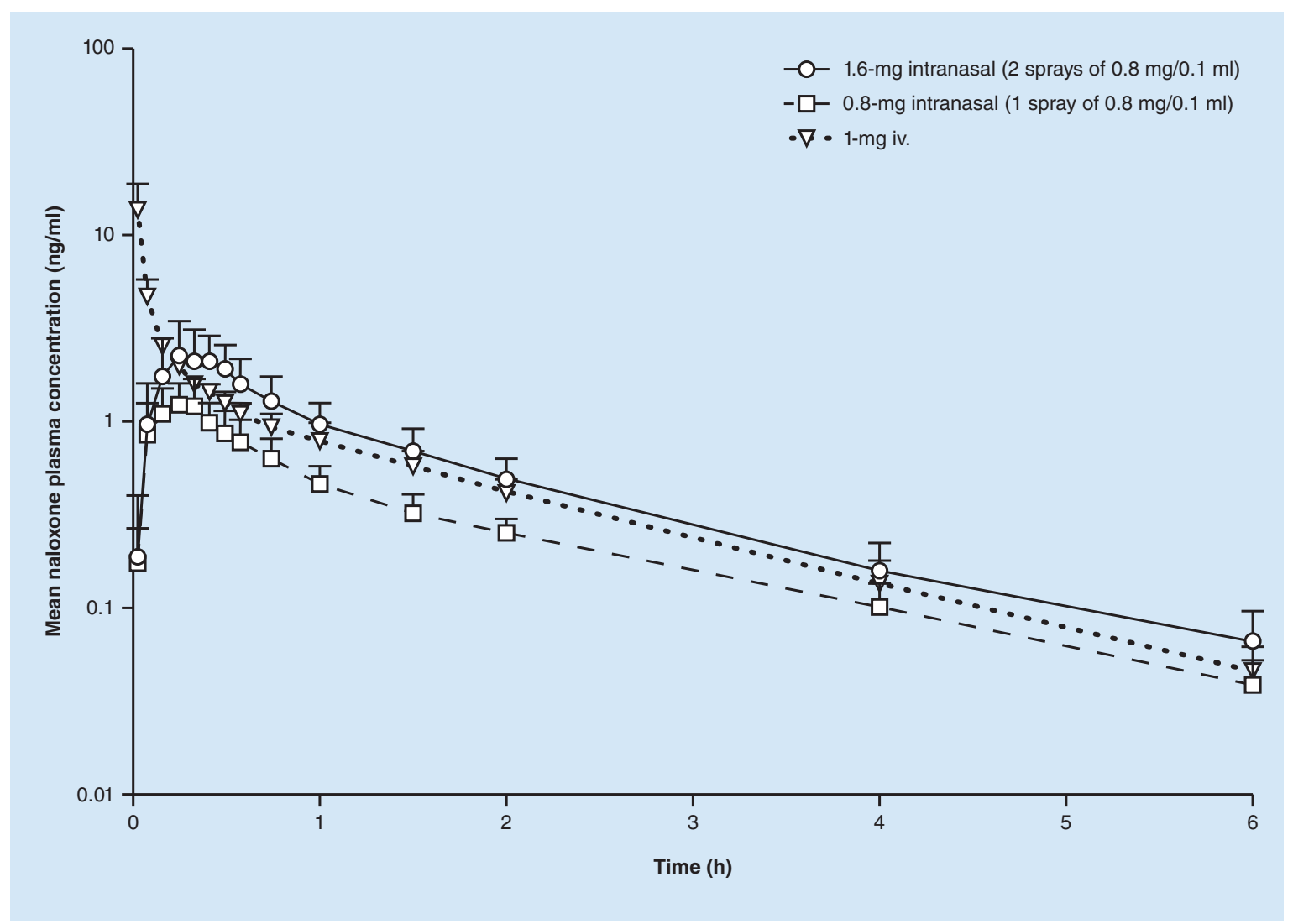

Figure 6. Time course of plasma concentrations (mean [error bars $95 \%$ confidence interval]) of naloxone after intravenous $(1.0 \mathrm{mg})$ and intranasal $(0.8$ and $1.6 \mathrm{mg})$ administration in healthy human volunteers $(\mathrm{n}=12 \mathrm{for}$ intravenous and intranasal $\mathbf{0 . 8} \mathbf{m g}, \mathrm{n}=11 \mathrm{for}$ intranasal $1.6 \mathrm{mg}$ ). Squares are the $0.8 \mathrm{mg}$ intranasal, dots are the $1.6 \mathrm{mg}$ intranasal and triangles are the $1.0 \mathrm{mg}$ iv. [36].

$\mathrm{Cl}$ : Confidence interval; iv.: Intravenous.

Adapted with permission from [36] () Springer (2017).

Healthcare providers may consider giving a naloxone prescription to patients with chronic pain with a daily opioid dose $\geq 50 \mathrm{MME}$ and to all patients who are known or suspected users of illicit opioids.

Selection of the optimal community-use naloxone product depends on patient-specific and product-specific factors. Approved intranasal naloxone is appropriate for most patients, with the exception of those with known nasal pathology (e.g., polyps and chronic intranasal drug use [e.g., heroin and cocaine]). Auto-injector delivery of naloxone is im. or sc., based on the depth of the needle relative to the patient's clothing and adipose tissue. Because information about sc. absorption of naloxone is limited, we suggest that use of approved intranasal naloxone is preferred in patients who are overweight (BMI of $25-30 \mathrm{~kg} / \mathrm{m}^{2}$ ) or obese (BMI $>30 \mathrm{~kg} / \mathrm{m}^{2}$ ).

When selecting the dose of a community-use product, the need for the maximum available safe dose of naloxone (that does not harm the patient) is paramount. For high-concentration, low-volume intranasal spray formulations (both approved and in development), bioavailability relative to im. administration was approximately $50 \%$ (Table 2), indicating that similar overall naloxone exposure would be achieved with a 4-mg intranasal dose (using a highconcentration product) and a $2-\mathrm{mg} \mathrm{im}$. dose. For the approved intranasal spray, $4 \mathrm{mg}$ is the first dose of the product approved by the FDA and is considered the standard dose for this product; the 2-mg dose is indicated only for patients considered at risk of severe opioid withdrawal [54]. If members of the patient's household are at risk for accidental or intentional exposure to opioids, the 4-mg dose of the approved intranasal spray is indicated. Because the 0.4-mg dose will be discontinued, the im./sc. auto-injector should be prescribed at the 2-mg dose [53].

As with any medication, cost and availability are relevant concerns for patients and their families and caregivers. Prescribers should take into consideration potential socioeconomic barriers to obtaining naloxone products (e.g., insurance coverage and out-of-pocket costs). Although cost is one of the most relevant barriers to gaining 
access to naloxone, standard metrics for comparing medication costs (e.g., wholesaler acquisition cost) do not reflect the actual costs of these products to patients. FDA-approved naloxone products are covered by most insurers (commercial and public), often with low (or no) copays. For patients without insurance coverage, clinicians can identify community organizations that may provide naloxone at no cost.

For community-use naloxone, ease of use under stressful conditions is also of critical importance. Consideration should be given to providing the community-use naloxone product directly to patients, since overdose may occur before a naloxone prescription is filled if dispensing pharmacy resources are not easily available. Education of patients, family members and companions in the use of the naloxone product selected may be provided by nursing staff, as is typical for other newly prescribed medications such as inhalers, epinephrine auto-injectors or glucometers, although naloxone products will universally be administered by bystanders in a community-use setting. The integration of public health resources into emergency departments may serve to reach at-risk and underserved populations [61]. Similarly, public health programs for opioid overdose prevention may target patients who are at-risk users of opioids (via either legitimate prescriptions or illicit sources).

\section{Limitations}

Despite a search of recent congress presentations, as well as MEDLINE and Embase, relatively few studies were identified. Methodology varied across studies, including differences in the reference products used, injection sites for the reference im. products, AUC parameters reported and statistical analyses performed. In addition, study participants were primarily healthy volunteers rather than the intended population for naloxone prescription (i.e., patients at risk for opioid overdose). Because of copyright restrictions, it was not possible to show AUC curves for all naloxone products available for community use.

\section{Conclusion}

The US opioid epidemic continues to worsen; unintentional overdose of prescription and illicit opioids remain all too common. Two naloxone products for community use have been approved by the FDA (based on compliance with good manufacturing practice requirements for combination [i.e., drug plus device] products, human use/label comprehension studies and pharmacokinetic studies) and have been used successfully by laypersons to reverse opioid overdose. Prescriptions for community-use naloxone may reduce future risk in patients who are receiving chronic opioid therapy for pain control or who have histories of illicit opioid use. Selection of community-use naloxone formulation and dose is based on product- and patient-specific characteristics. It is imperative that providers take into account the need for the maximum available safe dose of naloxone (especially in areas where synthetic opioids such as fentanyl are prevalent). It is also important to prescribe community-use formulations that are simple to use and appropriate for the individual patient.

\section{Future perspective}

Turning the tide on the epidemic of opioid overdose deaths will require a multifaceted approach that includes safer opioid prescribing, increased access to treatment programs for opioid abuse (e.g., medication-assisted treatment with behavioral therapies) and increased access to naloxone for opioid overdose reversal [2]. Recent US data indicate that opioid prescribing decreased from 2010 through 2015 but remained three-times greater than 1999 levels [62]. Wider access to community-use naloxone (in adequate dosages and easy-to-use formulations) is important for reducing the number of opioid-related deaths in the coming years.

\section{Financial \& competing interests disclosure}

SA Ryan reports serving as a consultant to Adapt Pharma, Inc. and serving as a consultant to Braeburn Pharmaceuticals, Inc. RB Dunne reports no relevant financial relationships to disclose. The authors have no other relevant affiliations or financial involvement with any organization or entity with a financial interest in or financial conflict with the subject matter or materials discussed in the manuscript apart from those disclosed.

Writing assistance was utilized in the production of this manuscript. Medical writing/editorial support were provided, under the direction of the authors, by N Holland, Synchrony Medical Communications, LLC, PA, USA, and sponsored by Adapt Pharma, Inc., PA, USA. 


\section{Open access}

This work is licensed under the Attribution-NonCommercial-NoDerivatives 4.0 Unported License. To view a copy of this license, visit http://creativecommons.org/licenses/by-nc-nd/4.0/

\section{References}

Papers of special note have been highlighted as: $\bullet$ of interest; $\bullet \bullet$ of considerable interest

1. Centers for Disease Control and Prevention. NCHS data on drug-poisoning deaths (2016). https://www.cdc.gov/nchs/data/factsheets/factsheet_drug_poisoning.htm

2. Rudd RA, Aleshire N, Zibbell JE, Gladden RM. Increases in drug and opioid overdose deaths - United States, 2000-2014. MMWR Morb. Mortal. Wkly Rep. 64(50-51), 1378-1382 (2016).

- CDC summary of US national data on opioid overdose mortality.

3. Rudd RA, Seth P, David F, Scholl L. Increases in drug and opioid-involved overdose deaths - United States, 2010-2015. MMWR Morb. Mortal. Wkly Rep. 65(50-51), 1445-1452 (2016).

4. Peterson AB, Gladden RM, Delcher C et al. Increases in fentanyl-related overdose deaths - Florida and Ohio, 2013-2015. MMWR Morb. Mortal. Wkly Rep. 65(33), 844-849 (2016).

5. Lucyk SN, Nelson LS. Toxicosurveillance in the US opioid epidemic. Int. J. Drug Policy 46, 168-171 (2017).

6. Lucyk SN, Nelson LS. Novel synthetic opioids: an opioid epidemic within an opioid epidemic. Ann. Emerg. Med. 69(1), 91-93 (2017).

7. Albert M, McCaig LF, Uddin S. Emergency Department Visits for Drug Poisoning: United States, 2008-2011. US Department of Health \& Human Services, MD, USA (2015).

8. Yokell MA, Delgado MK, Zaller ND, Wang NE, McGowan SK, Green TC. Presentation of prescription and nonprescription opioid overdoses to US emergency departments. JAMA Intern. Med. 174(12), 2034-2037 (2014).

9. Handal KA, Schauben JL, Salamone FR. Naloxone. Ann. Emerg. Med. 12(7), 438-445 (1983).

10. Wermeling DP. Review of naloxone safety for opioid overdose: practical considerations for new technology and expanded public access. Ther. Adv. Drug Saf. 6(1), 20-31 (2015).

11. Compton WM, Volkow ND, Throckmorton DC, Lurie P. Expanded access to opioid overdose intervention: research, practice, and policy needs. Ann. Intern. Med. 158(1), 65-66 (2013).

12. Wheeler E, Jones TS, Gilbert MK, Davidson PJ. Opioid overdose prevention programs providing naloxone to laypersons - United States, 2014. MMWR Morb. Mortal. Wkly Rep. 64(23), 631-635 (2015).

13. Califf RM, Woodcock J, Ostroff S. A proactive response to prescription opioid abuse. N. Engl. J. Med. 374(15), 1480-1485 (2016).

- Summary of US FDA actions in addressing the public health crisis of prescription opioid abuse.

14. Strang J, McDonald R, Tas B, Day E. Clinical provision of improvised nasal naloxone without experimental testing and without regulatory approval: imaginative shortcut or dangerous bypass of essential safety procedures? Addiction 111(4), 574-582 (2016).

15. Barton ED, Colwell CB, Wolfe T et al. Efficacy of intranasal naloxone as a needleless alternative for treatment of opioid overdose in the prehospital setting. J. Emerg. Med. 29(3), 265-271 (2005).

16. Kerr D, Kelly AM, Dietze P, Jolley D, Barger B. Randomized controlled trial comparing the effectiveness and safety of intranasal and intramuscular naloxone for the treatment of suspected heroin overdose. Addiction 104(12), 2067-2074 (2009).

17. Weber JM, Tataris KL, Hoffman JD, Aks SE, Mycyk MB. Can nebulized naloxone be used safely and effectively by emergency medical services for suspected opioid overdose? Prehosp. Emerg. Care 16(2), 289-292 (2012).

18. Rando J, Broering D, Olson JE, Marco C, Evans SB. Intranasal naloxone administration by police first responders is associated with decreased opioid overdose deaths. Am. J. Emerg. Med. 33(9), 1201-1204 (2015).

19. Fisher R, O’Donnell D, Ray B, Rusyniak D. Police officers can safely and effectively administer intranasal naloxone. Prehosp. Emerg. Care 20(6), 675-680 (2016).

20. Doe-Simkins M, Walley AY, Epstein A, Moyer P. Saved by the nose: bystander-administered intranasal naloxone hydrochloride for opioid overdose. Am. J. Public Health 99(5), 788-791 (2009).

21. Edwards ET, Edwards ES, Davis E, Mulcare M, Wiklund M, Kelley G. Comparative usability study of a novel auto-injector and an intranasal system for naloxone delivery. Pain Ther. 4(1), 89-105 (2015).

-• Human factors study of the usability of naloxone auto-injector and improvised intranasal naloxone kit.

22. Edwards E, Edwards E, Kelley G, Fink N, Dissinger E, Shames A. Comparative simulated use study of a novel auto-injector and nasal delivery device for naloxone administration. Postgrad. Med. 128(Suppl. 2), 24-25 (2016).

23. $\mathrm{EVZIO}^{\circledR}$ (naloxone hydrochloride injection) auto-injector for intramuscular or subcutaneous use, package insert. Kaléo, Inc., VA, USA (2014). https:

//dailymed.nlm.nih.gov/dailymed/fda/fdaDrugXsl.cfm?setid=df501ed0-c0f4-11e3-8a33-0800200c9a66\&type=display 
24. $\mathrm{EVZIO}^{\circledR}$ (naloxone hydrochloride injection) auto-injector for intramuscular or subcutaneous use $2 \mathrm{mg}$, package insert. Kaléo, Inc., VA, USA (2016).https: //dailymed.nlm.nih.gov/dailymed/fda/fdaDrugXsl.cfm?setid=5fbe8d17-a72f-406d-a736-48e61620f9d8\&type=display

25. NARCAN $^{\circledR}$ (naloxone hydrochloride) nasal spray, package insert. Adapt Pharma, Inc., PA, USA (2017). https://www.narcan.com/pdf/NARCAN-Prescribing-Information.pdf

26. US FDA. Current Good Manufacturing Practice Requirements for Combination Products. US FDA, MD, USA (2017). http://www.fda.gov/RegulatoryInformation/Guidances/ucm126198.htm

27. Elzey MJ, Fudin J, Edwards ES. Take-home naloxone treatment for opioid emergencies: a comparison of routes of administration and associated delivery systems. Expert Opin. Drug Deliv. 16, 1-14 (2016).

28. US FDA. Human Factors Studies and Related Clinical Study Considerations in Combination Product Design and Development. US FDA, MD, USA (2016). https://www.fda.gov/downloads/RegulatoryInformation/Guidances/UCM484345.pdf

29. Birmingham LE, Nielson JA. An increase in per-patient naloxone requirements in an opioid epidemic. Am. J. Emerg. Med. 35(12), 1958-1959 (2017).

30. Faul M, Lurie P, Kinsman JM, Dailey MW, Crabaugh C, Sasser SM. Multiple naloxone administrations among emergency medical service providers is increasing. Prehosp. Emerg. Care 21(4), 411-419 (2017).

31. Edwards ES, Gunn R, Kelley G, Smith A, Goldwater R. Naloxone $0.4 \mathrm{mg}$ bioavailability following a single injection with a novel naloxone auto-injector, EVZIO ${ }^{\circledR}$, in healthy adults, with reference to a $1 \mathrm{~mL}$ standard syringe and intramuscular needle. Presented at: American Academy of Pain Medicine. MD, USA16-22 March 2015.

-. Pharmacokinetic study of naloxone auto-injector compared with standard syringe and needle for intranuscular naloxone injection.

32. Krieter P, Chiang N, Gyaw $S$ et al. Pharmacokinetic properties and human use characteristics of an FDA-approved intranasal naloxone product for the treatment of opioid overdose. J. Clin. Pharmacol. 56(10), 1243-1253 (2016).

-• Pharmacokinetic study of approved intranasal naloxone compared with intramuscular naloxone injection, and human factors study on the usability of approved intranasal naloxone.

33. Edwards ES, Kessler CL, Kelley G, Gapasin A, Mardari G, Goldwater R. Pharmacokinetics of 2.0mg intranasal and intramuscular naloxone $\mathrm{HCl}$ administration and the impact of vasoconstrictor use on the bioavailability of intranasal naloxone $\mathrm{HCl}$. Presented at: American Academy of Pain Medicine. CA, USA, 18-21 February 2016

34. Dowling J, Isbister GK, Kirkpatrick CM, Naidoo D, Graudins A. Population pharmacokinetics of intravenous, intramuscular, and intranasal naloxone in human volunteers. Ther. Drug Monit. 30(4), 490-496 (2008).

35. McDonald R, Lorch U, Woodward J et al. Pharmacokinetics of concentrated naloxone nasal spray for opioid overdose reversal: Phase I healthy volunteer study. Addiction 113(3), 484-493 (2017).

36. Tylleskar I, Skulberg AK, Nilsen T, Skarra S, Jansook P, Dale O. Pharmacokinetics of a new, nasal formulation of naloxone. Eur. J. Clin. Pharmacol. 73(5), 555-562 (2017).

37. Strang J, Lorch U, McDonald R et al. A concentrated naloxone nasal spray for opioid overdose reversal: a pharmacokinetic study in healthy volunteers. Presented at: Society for the Study of Addiction Annual Conference. Newcastle upon Tyne, UK, 10-11 November 2016

38. Mundin G, McDonald R, Smith K, Harris S, Strang J. Pharmacokinetics of concentrated naloxone nasal spray over first 30 minutes post-dosing: analysis of suitability for opioid overdose reversal. Addiction 112(9), 1647-1652 (2017).

39. Vanky E, Hellmundt L, Bondesson U, Eksborg S, Lundeberg S. Pharmacokinetics after a single dose of naloxone administered as a nasal spray in healthy volunteers. Acta Anaesthesiol. Scand. 61(6), 636-460 (2017).

40. Gufford BT, Ainslie GR, White JR Jr et al. Comparison of a new intranasal naloxone formulation to intramuscular naloxone: results from hypothesis-generating small clinical studies. Clin. Transl. Sci. 10(5), 380-386 (2017).

41. Wermeling DP. A response to the opioid overdose epidemic: naloxone nasal spray. Drug Deliv. Transl. Res. 3(1), 63-74 (2013).

42. Robinson A, Wermeling DP. Intranasal naloxone administration for treatment of opioid overdose. Am. J. Health Syst. Pharm. 71(24), 2129-2135 (2014).

43. van Dorp E, Yassen A, Dahan A. Naloxone treatment in opioid addiction: the risks and benefits. Expert Opin. Drug Saf. 6(2), 125-132 (2007).

44. McDonald R, Danielsson Glende O, Dale O, Strang J. International patent applications for non-injectable naloxone for opioid overdose reversal: exploratory search and retrieve analysis of the PatentScope database. Drug Alcohol Rev. 37(2), 205-215 (2017).

45. Strang J, McDonald R, Alqurshi A, Royall P, Taylor D, Forbes B. Naloxone without the needle - systematic review of candidate routes for non-injectable naloxone for opioid overdose reversal. Drug Alcohol Depend. 163, 16-23 (2016).

46. Rzasa Lynn R, Galinkin JL. Naloxone dosage for opioid reversal: current evidence and clinical implications. Ther. Adv. Drug Saf. 9(1), 63-88 (2018).

47. van der Schier R, Roozekrans M, van Velzen M, Dahan A, Niesters M. Opioid-induced respiratory depression: reversal by non-opioid drugs. F1000Prime Rep. 6, 79 (2014). 
48. Investor News. Indivior receives complete response letter from FDA not approving naloxone nasal spray new drug application for opioid overdose. Indivior Inc., Slough, UK (2015). http://www.indivior.com/investor-news/indivior-receives-complete-response-letter-from-f da-not-approving-naloxone-nasal-spray-new-drug-application-for-opioid-overdose

49. Boyer EW. Management of opioid analgesic overdose. N. Engl. J. Med. 367(2), 146-155 (2012).

50. Clarke SF, Dargan PI, Jones AL. Naloxone in opioid poisoning: walking the tightrope. Emerg. Med. J. 22(9), 612-616 (2005).

51. US FDA. Joint Meeting of Anesthetic and Analgesic Drug Products Advisory Committee and Drug Safety and Risk Management Advisory Committee. US FDA, MD,

USA (2016). http://prescribetoprevent.org/wp2015/wp-content/uploads/Naloxone-product-chart.17_04_14.pdf

52. Fiore K. FDA splits on naloxone dose. MedPage Today (2016). http://medpagetoday.com/neurology/generalneurology/60632

53. EVZIO $^{\circledR}$ (naloxone HCI injection) $2 \mathrm{mg}$ auto-injector (2016). https://evzio.com/hcp/

54. NARCAN ${ }^{\circledR}$ (naloxone HCI) nasal spray 2 mg approved by US FDA. Adapt Pharma, Inc., PA, USA (2017). http: //adaptpharma.com/adapt_press_release/january-25--2017-narcan-nasal-spray-2mg-approved-by-us-food-and-drug-administration/

55. Avetian GK, Fiuty P, Mazzella S, Koppa D, Heye V, Hebbar P. Use of naloxone nasal spray $4 \mathrm{mg}$ in the community setting: a survey of use by community organizations. Curr. Med. Res. Opin. 34(4), 573-576 (2017).

56. Kestler A, Buxton J, Meckling G et al. Factors associated with participation in an emergency department-based take-home naloxone program for at-risk opioid users. Ann. Emerg. Med. 69(3), 340-346 (2017).

57. Gianutsos G. Expanding access to naloxone: role of the pharmacist. US Pharmacist (2016). https://www.uspharmacist.com/ce/expanding-access-to-naloxone-role

58. Weaver L, Palombi L, Bastianelli KMS. Naloxone administration for opioid overdose reversal in the prehospital setting: implications for pharmacists. J. Pharm. Pract. 31(1), 91-98 (2018).

59. Bailey AM, Wermeling DP. Naloxone for opioid overdose prevention: pharmacists' role in community-based practice settings. Ann. Pharmacother. 48(5), 601-606 (2014).

60. Dowell D, Haegerich TM, Chou R. CDC guideline for prescribing opioids for chronic pain - United States, 2016. JAMA 315(15), 1624-1645 (2016).

-. $\quad$ CDC prescribing guideline with a focus on the benefits and risks of opioids for chronic pain.

61. Lyons MS, Lindsell CJ, Ledyard HK, Frame PT, Trott AT. Health department collaboration with emergency departments as a model for public health programs among at-risk populations. Public Health Rep. 120(3), 259-265 (2005).

62. Guy GP Jr, Zhang K, Bohm MK et al. Vital signs: changes in opioid prescribing in the United States, 2006-2015. MMWR Morb. Mortal. Wkly Rep. 66(26), 697-704 (2017). 
